\title{
TEACHERS' COMPETENCES FOR EDUCATIONAL WORK
}

Antea Čilić Department of Pedagogy, Faculty of Science and Education, University of Mostar

Anita Klapan

Department of Pedagogy, Faculty of Humanities and Social Sciences, University of Rijeka

Maja Prnić

Mostar

\begin{abstract}
Competence is a combination of knowledge, skills, attitudes, motivation and personal characteristics enabling individuals to act actively and efficiently in a certain (specific) situation. In the time of large social and technological change teachers' role change as well. Modern changes in the u overall nurture and education system require teachers to take new roles. The aim of this paper is to explore teachers' competence in the nurture-education process. The results show that teachers are very satisfied with the functioning of working with students. Most of them plan to work in accordance with the objectives and outcomes of each subject, using appropriate methods and techniques, they are satisfied with the training courses, cooperation with parents and the process of evaluating student achievement. A competent teacher should affect their work on improving the overall quality of the school as it would not only be a place of acquisition and reproduction of knowledge but also a place of interaction, communication, tolerance, and freedom of expression and critical thinking.
\end{abstract}

Key words: competence, teacher, student, educational process, evaluation, quality schools, academic achievements. 


\section{Theoretical approach}

\section{Teacher competencies in the field of building curriculum classes}

According to Matijevic (2010) curriculum is a project or a pedagogical document which is prepared and drafted by experts in certain teaching area, and in which are specified learning objectives, described conditions and equipment that are required to achieve those objectives and planned models for monitoring and evaluation.

Curriculum construction of modern school is based on self-evaluation of management, efficiency and atmosphere of school staff. The modern school curriculum, which clearly indicates the function of the school, and the development of autonomy, with flexible organizational models, asks employees to work as a team with the characteristics of teamwork. With the knowledge and skills that the process of education should achieve, the school curriculum must include the value of which would be at the school should adopt, should define the objectives to be attained education schools (which along with cognitive, necessarily including the value component), but also ways which they want to achieve, which is not limited only to the ways of teaching and learning, but also include the relationships between school staff (Jurcic, 2012).

Sekulic-Majurec (2009) describes the role of different social and political change and participants in the educational process in the design, implementation and evaluation of school curricula, it cites the key role of principals in the formation of the specific targets of school, take care of the school culture and professional development of teachers. School evaluation and self-assessment is the way to quality and excellence. Pedagogical standards and / or indicators of quality and excellence are guidelines to assist in monitoring, assessment, self-assessment, and evaluation of the effects of schooling. The objectives of the evaluation and self-evaluation of teachers are associated with quality assurance of the teaching process and the teacher's professional development in order to achieve a high level of professional aspiration; openness to change; the will to experiment in their teaching and openness to criticism and self-criticism; good knowledge of all aspects of teaching the subject and educational areas. If we want to develope quality teachers and improve their professional, it is desirable to promote mutual exchanges of successes in the process of self-evaluation. Presenting strategies that the teachers use, and experiences they had, they will learn from each other, creating a sense of pride and interconnectedness. Therefore, constructive debates are welcome and are an integral part of evaluation and self-evaluation as an active process (Buljubašić-Kuzmanovic, Kretic Meyer, 2008). 
According Domović (2009) contemporary needs and business requirements at the same time looking, but also offer the possibility of continuous professional development and continuing education in the form of three main groups of competences for teachers; work with information, knowledge and technology, working with people and work in the community and for the community.

\section{Teacher competencies in the field of organizing and managing the educational process}

Teacher competencies in the field of organizing and managing the educational process cannot be described as a system of rules, or can be developed only on the basis of respect expressed and formally present rules. They acquire and develop learning and action, following the procedures of teaching and students' progress in learning.

A competent teacher in the field of organizing and conducting educational process works with students understand, prepares and realizes so that: A competent teacher tries to adapt teaching and learning, and to win over the students according to their own possibilities, which are more conducive to the common cause (education students). As important features competent organization and management of the educational process stands out rational use of time and space, the implementation of teaching that encourages students to the activity and learning. (Jurcic, 2012). The cooperation of teachers and students and the teacher's guidance on the development of human classes characterized by cooperation, understanding, friendship, mutual respect, appreciation, communication as a prerequisite for the development of students' competencies and technological culture, moral and spiritual stability, or all that they could, to live, work and enjoy the community leads to quality in the organization and management of the educational process leads (Previsic, 2000).

\section{Teacher competencies in the area of determining the efficiency of achievement at school}

A competent teacher is the one who understands the theoretical level and in their practice applie the most important determinants of evaluation and assessment of students, and those are: school to assessments of students' success in learning derived from assumptions for learning (skills, motivation, interest, work ethic, commitment, learning conditions and the like); the level of students' knowledge (reach degree of understanding and application, procedures and propositions); evaluation criteria (fairness) and objectivity (in the forms and methods); continuity and the public; written notes as a prerequisite for a number evaluation or as a descriptive grade; interpretation of the results of student achievement in oral or written verification or practical tasks completed and the possible elimination of the fear of school 
failure; some special features in the process of determining the value of the students' achievements in the course of cooperative learning and for students with disabilities (Jurcic, 2012).

From the research results (Tot, 2010) it is apparent an understanding of the purpose of evaluation of teaching by students, but also the awareness that evaluation is carried out in an appropriate manner. Testing and evaluation knowledge is an inseparable part of the unique educational process. Teachers almost every day, check and evaluate the knowledge of their students, without such control their educational achievement has at least two functions: a) to obtain information about the kind of success students acquire and the government of the facilities (which allows them to monitor their educational development), b) provided they obtain feedback on their teaching so they could more appropriate and more successful design and implement (Grgin 1986).

The school assessment of knowledge is, by its nature, measuring knowledge. Each evaluation given by the teacher has a function to control the students' knowledge, his intelligence, general school behavior, adaptation of school criteria (Fulgosi, 1980). The purpose of the evaluation of student achievement is associated with selection to continue their education, motivation for learning, focusing learning, correction of errors and evaluation of teaching and learning (Matijevic, 2004).

\section{Teacher competencies in the field of design classroom atmosphere}

School climate (atmosphere) is usually defined as a set of internal characteristics that schools are different and that affect the behavior of its members, and thus indirectly on the quality of educational processes and outcomes. Earn school climate at the same time and the effect itself and the factor that affects the other effects of school. There is a correlation between school climate and a sense of trust between teachers and trust between teachers and principals (Domovic, 2004).

The teaching process is a joint work of students and teachers, and as such, should include consultation, download of individual tasks, and the achievement of the agreed valuation performed. Various research projects, development of class newspapers, going on picnics, learning games, and correspondence with students from other schools, contribute to a climate that encourages the achievement of the goals of human rights education. The result of such activities is usually not possible to measure and evaluate tests of numerical estimates, but it should be borne in mind that they are in life more important than the variety of information that are subject to evaluation (Spajic Vrkas et al., 2004). 
The class atmosphere that a teacher can establish has a strong impact on students' motivation and attitude towards learning. Therefore, the art of establishing of a positive classroom atmosphere is especially important. The class atmosphere which is generally considered as one which best encourages pupils to learn is the one that is described as purposeful, hardworking, relax, friendly, stimulat and tidy. Such an atmosphere facilitates learning time as establishing and maintaining a positive attitude and motivation of students for the lesson. When the breakdown skill required to establish a positive classroom atmosphere, it is obvious that this atmosphere is largely based on the implicit values that pervade nastavu- and that is that the students and their learning so important (Kyriacou, 1998).

The school and classroom climate are logically interconnected and are in the "interconnection" established "mutual relations", which means that the study of classroom atmosphere it is necessary to know the basic factors of school climate and vice versa (Jurcic, 2012).

\section{Teacher competencies in the field of educational partnership with parents}

One of the important features of an effective school is developing cooperation with parents. There are many reasons why parents and teachers should meet more often and communicate the objectives of education and development of children.

Bakker et al. (2007) in Maricic et al. (2009) distinguish three aspects of parental involvement in a child's education: educational activities at home, communicating with the school and participate in school activities.

Vizek Vidovic et al. (2003) suggest a number of practical tips for teachers to increase the possibilities for good cooperation. For example, communication with parents should be established at the beginning of the school year, not when there is a problem. Establish communication should be maintained throughout the school year through various forms, including informal contacts. The teacher should also get to know each family by the students through a discussion with parents, the student, the student entering the task of writing an essay on the subject and the like.

According Maricic et al. (2009) parental involvement in a child's education, attitudes about the existing school system, and the expectations of changes are significant independent determinants of parental general attitude towards schools effectiveness. 


\section{Methodological approach}

The aim of this study was to determine the competence of teachers in the educational process. The study was conducted on a sample of teachers from Primary School Orebic. The sample was special. In order to achieve the objective and tasks of research and perform the appropriate conclusions were used method of theoretical analysis and descriptive- analytical method.

The instrument of data collection was a questionnaire for teachers designed for the purposes of this research, which consisted of 29 claims on the Likert scale of 5 degrees.

\section{Results and discussion:}

Ensuring quality education that would effectively respond to the new needs and interests of individuals and society includes the question of competence of teachers in the educational work. This research led to the insight into the competence of teachers in the different segments of the teaching process, and the ways in which teachers themselves perceive themselves to interact with all stakeholders of the school and contribute to improving the quality of school life. They further isolated, presentation and analysis of key issues of competence of teachers tested questionnaire.

On the statement, "In planning the content and methods of work is guided by the objectives and outcomes of the subject" agree almost all teachers. Thus, $48 \%$ completely agree with the above statement, an identical number of teachers agreed with this statement while only $5 \%$ of teachers disagreed with this statement. Teachers play a crucial role in the education of students, and it is advisable that to achieve the objectives using appropriate content and ways of working. All teachers use methods and techniques appropriate to the case, but their pupils.

The contents of the case submitted by the example from everyday life and experiences connect almost all teachers. $52 \%$ of teachers agree that in planning and organizing fully guided educational standards. $33 \%$ of respondents agreed with the statement, $10 \%$ neither agreed nor disagreed while $5 \%$ of them do not agree with this statement. $43 \%$ of teachers in the statement that claimed a possible vocational training and that they are satisfied with the possibilities of further improvement responded to and agree and disagree. $14 \%$ of teachers are fully agree with this statement, while $33 \%$ of teachers agree with this statement. $5 \%$ of teachers disagreed and certainly does not agree with the above statement. 
In the statement, "I believe that every student has their own style of learning and progressing in accordance with their abilities because I approach each student individually" obtained by the check results, so the $52 \%$ of teachers in full agreement with the statement, $24 \%$ agreed. This finding was true for the teachers agree to know and use different ways of monitoring and evaluation work. Of these, fully $43 \%$ of teachers agree, agree $48 \%$ of teachers, and agrees and disagrees $10 \%$ of teachers.

$38 \%$ of teachers are fully agrees to use student achievement as an indicator of the efficiency and effectiveness of their work, $43 \%$ of them agree with the statement while $19 \%$ agree and disagree with the statement. It is important to inform students about their achievements, but also elements that need to be improved because it can be a stimulus for new developments or to improve in those areas where the perceived shortcomings.

All the teachers think that the goals of their work aimed at improving the quality of learning and to better student achievement, so this claim is confirmed. Reply strongly agree yielded $76 \%$ and $24 \%$ disagree teachers.

The results show that teachers are very satisfied with the functioning of working with students. Most of them planned to work in accordance with the objectives and outcomes of each subject, using appropriate methods and techniques, and connect them with the amenities of daily life. Also, teachers are satisfied with the training courses. It is important that teachers are willing to constantly learn, upgrade the knowledge and the practical application thereof. Lifelong learning is a prerequisite for the quality of work, as well as the overall educational quality. Evaluation and monitoring of student progress and achievement is certainly one of the indicators of quality, with which agrees the majority of respondents in this study. Since the quality of education in part be predicted on the basis of the possibilities offered by the surroundings, the first family, the paper highlights the importance of parental involvement in the educational process, as well as a positive school climate that affects the behavior of all members and based on common perception, behavior in school, as an important factor in the overall quality of school.

\section{CONCLUSION}

In education teacher has a very important role. With changing needs of students comes changing role of teachers. The paper stresses the importance of competence in the construction of curriculum, knowledge of technology, evaluation and self-evaluation of their work, social competence, emotional competence, the importance of teachers 'work with students with special needs, teachers' competences in the field of organizing and managing the educational process, evaluation 
and assessment of students, Professional development of teachers. It also pointed out that the establishment of a teacher classroom atmosphere can strongly affect the motivation of students, and how the success of a child is important competence of teachers in the educational partnership with parents. The teacher should be prepared to meet the challenges faced by, and be the initiator of changes in promoting understanding and tolerance. Without competent and quality teachers there is no quality education, and therefore no good educational outcomes, which leads to the conclusion that teachers should be open and willing to change and motivated for lifelong learning and continuous professional development

\section{LITERATURE}

Buljubašić- Kuzmanović V., Kretić Majer J. (2008). Vrednovanje i samovrednovanje u funkciji is -traživanja i unapređivanja kvalitete škole, Pedagogijska istraživanja, br.5, str. 139-151.

Domović, V. (2004). Školsko ozračje i učinkovitost škole, Zagreb, Naknada slap

Fulogosi, A., Fulogosi, Lj. (1980). Faktorska struktura i konstruktna valjanost školskih ocjena, Revija za psihologiju, str. 39-45

Grgin, T. (1986). Školska dokimologija, Zagreb, Školska knjiga

Jurčić, M (2006) Učenikovo opterećenje nastavom i razredno- nastavno ozračje, Odgojne znanosti,

Vol.8, br. 2, str. 329-346.

Jurčić, M. (2012.) Pedagoške kompetencije suvremenog učitelja, Zagreb, Recedo

Koch, L. (2008). Nemjerljive kompetencije učitelja, Odgojne znanosti, Vol. 10, br. 1 str. 23-38.

Kyriacou, C. (1998). Temeljna nastavna umijeća, Zagreb, Educa

Maričić, J. (2009). Roditeljsko zadovoljstvo školom i stav prema promjenama u školstvu : uloga roditeljskih ulaganja i očekivanih posljedica promjena. Društvena istraživanja. 4/5(102/103);str. 625-648.

Matijević, M., (2010). Između didaktike nastave usmjerene na učenika i kurikulumske teorije. U: Zbornik radova četvrtog kongresa matematike. Zagreb: Hrvatsko matematičko društvo i Školska knjiga, str: 391-408.

Previšić, V. (2000). Suvremeni modeli i sadržaji obrazovanja i usavršavanja pedagoga U: Vrgoč, H. (ur.) Pedagozi- stručni suradnici u inovacijskom vrtiću i školi. Zagreb: HPKZ.

Sekulić-Majurec, A. (2007), Uloga sudionika odgojno-obrazovnog procesa u stvaranju, provedbi i vrednovanju kurikuluma. U: Previšić, V. (ur.), Kurikulum: teorije-metodologija-sadržaj-struk tura. Zagreb: Zavod za pedagogiju Filozofskog fakulteta u Zagrebu - Školska knjiga, 351-383.

Spajić Vrkaš, V., Stričević, I., Maleš, D., Matijević M. (2004). Poučavati prava i slobode, Istraživačko obrazovni centar za ljudska prava i demokratsko građanstvo, Filozofski fakultet Sveučiliš -ta u Zagrebu, Zagreb.

Vizek Vidović, V., Vlahović- Štetić, V., Rijavec, M. i Miljković, D. (2003). Psihologija obrazovanja, Zagreb, IEP- VERN 